\title{
KETERSEDIAAN RUANG TERBUKA HIJAU DAN URBAN HEAT ISLAND DI KOTA MAKASSAR
}

\author{
Rindi Kurnianti $^{1}$, Dwita Hadi Rahmi ${ }^{2}$ \\ ${ }^{1,2}$ Magister Perencanaan Wilayah dan Kota, Universitas Gadjah Mada \\ 1rindikurnianti@gmail.com
}

Diterima: Maret 2019; Direvisi: April 2019; Disetujui: Mei 2019

\begin{abstract}
Urban Heat Island (UHI) is a phenomenon where the temperature in urban areas relatively increased compared to rural areas that occured in many major cities of the world including Indonesia. Makassar as a city with high growth rate is one of the cities affected by this phenomenon. One of UHI's mitigation efforts is by increasing green open spaces (RTH) in urban areas. As an effort to mitigate UHI, it is necessary to analyze the area of RTH and UHI in Makassar City. This study used Landsat 8 imagery in 2013 and 2018 to analyze the area of RTH and UHI in Makassar City. Normalized Difference Vegetation Index (NDVI) is used as an indicator of vegetation coverage. The analysis was carried out in each sub-district to obtain a comparison of the vegetation area and UHI. The result shows that the mean temperatures in 2013 and 2018 in Makassar City had exceeded the normal threshold, which is $27^{\circ} \mathrm{C}$. Another result also shows that three subdistricts (Rappocini, Panakkukang, and Makassar) have high UHI values followed by a reduction in vegetation area during 2013-2018. The average temperature also increased from $28.42^{\circ} \mathrm{C}$ in 2013 to $29.54^{\circ} \mathrm{C}$ in 2018. Based on this research, strategies for mitigating UHI were formulated for Makassar City.
\end{abstract}

\section{Keyword: Green Open Spaces, NDVI, Urban Heat Island, UHI Mitigation.}

Abstraksi. Urban Heat Island (UHI) merupakan fenomena peningkatan relatif suhu di daerah urban dibandingkan rural yang banyak terjadi di kota-kota besar dunia termasuk di Indonesia. Makassar sebagai kota dengan tingkat pertumbuhan yang tinggi merupakan salah satu kota yang terdampak fenomena ini. Salah satu upaya mitigasi UHI adalah dengan meningkatkan luasan ruang terbuka hijau $(R T H)$ di daerah perkotaan. Sebagai upaya mitigasi UHI, perlu dilakukan analisis mengenai luasan RTH dan UHI di Kota Makassar. Penelitian ini menggunakan Citra Landsat 8 pada tahun 2013 dan 2018 untuk menganalisis luasan RTH dan UHI di Kota Makassar. Index vegetasi NDVI digunakan sebagai indikator luasan vegetasi pada citra. Analisis dilakukan pada tiap kecamatan sehingga diperoleh perbandingan luas vegetasi terhadap UHI. Hasil penelitian menunjukkan bahwa suhu rerata pada tahun 2013 dan 2018 di Kota Makassar telah melebihi ambang batas suhu nyaman yaitu melebihi $27^{\circ} \mathrm{C}$. Hasil lain menunjukkan bahwa tiga kecamatan (Rappocini, Panakkukang dan Makassar) memiliki nilai UHI yang tinggi diikuti dengan pengurangan luas vegetasi selama 2013-2018. Suhu rerata juga mengalami kenaikan dari $28,42^{\circ} \mathrm{C}$ pada tahun 2013 menjadi $29,54^{\circ} \mathrm{C}$ pada 2018. Dari hasil penelitian kemudian dirumuskan strategi untuk mitigasi UHI di Kota Makassar.

Kata kunci: RTH, NDVI, UHI, mitigasi UHI.

\section{PENDAHULUAN}

Kondisi kota besar yang dinamis menyebabkan perkembangan suatu kota melaju dengan sangat cepat. Umumnya pertumbuhan kota terjadi agar dapat memenuhi kebutuhan hidup masyarakat 
kota itu sendiri serta untuk meningkatkan kesejahteraan hidup. Meskipun demikian, perkembangan kota yang tidak terarah dapat menyebabkan timbulnya masalah tersendiri bagi lingkungan perkotaan tersebut. Menurut Yunus (2005), pada umumnya perkembangan kota besar yang ada di negara berkembang cenderung tidak terkendali. Kurangnya pemantauan yang ketat pada jalannya pembangunan perkotaan menyebabkan berbagai dampak negatif yaitu pemborosan energi dan materi, degradasi lingkungan dan naiknya suhu permukaan kawasan perkotaan.

Salah satu yang menjadi masalah dalam lingkungan perkotaan adalah naiknya suhu permukaan di sekitar kawasan terbangun dengan kepadatan yang tinggi. Naiknya suhu permukaan di kawasan perkotaan (urban) dibandingkan suhu di daerah pinggiran (rural) dinamakan dengan fenomena Urban Heat Island (UHI). Reuben (2012) mengatakan bahwa UHI merupakan suatu kondisi dimana suhu permukaan di pusat kota lebih tinggi dibandingkan suhu yang berada di daerah pinggiran. Darlina $d k k$. (2018) menjelaskan bahwa UHI terbentuk apabila permukaan yang seharusnya menyerap suhu panas dari matahari lebih banyak memantulkannya kembali ke udara dan terperangkap di dalam lingkup perkotaan. Permukaan tersebut lebih banyak memantulkan panas karena terjadinya alih fungsi lahan dari vegetasi menjadi lapisan aspal, beton, bangunan tinggi, dan infrastuktur lainnya yang digunakan untuk mengakomodasi kebutuhan dan pertambahan jumlah penduduk.

Gartland (2012) menyimpulkan lima karakteristik yang akan menghasilkan terbentuknya UHI di kota-kota besar, yaitu:

1) apabila terdapat suhu harian yang berbeda di pusat kota
2) terjadi peningkatan suhu pada saat matahari terbenam,

3) suhu panas dihasilkan dari panas permukaan perkotaan karena banyaknya objek buatan manusia yang menyerap panas matahari,

4) area dengan vegetasi kurang akan cenderung lebih panas dibandingkan area yang memiliki vegetasi lebih banyak, dan

5) udara yang dihasilkan oleh fenomena UHI ini akan lebih panas dengan batas mencapai 2000 meter.

Pada umumnya fenomena UHI sudah terjadi di kota-kota besar di dunia tidak terkecuali di kota-kota besar yang ada di Indonesia. Gaffin $d k k$. (2008) meneliti fenomena UHI di Kota New York dari tahun 1900 sampai tahun 2002. Hasil penelitiannya menunjukkan bahwa kondisi UHI di pusat Kota New York berkontribusi atas $1 / 3$ panas dari total pemanasan yang dialami kota tersebut.

Di Indonesia sendiri, beberapa penelitian telah dilakukan sehubungan dengan kondisi UHI di beberapa kota besar yakni di Jakarta, Surabaya, Yogyakarta, Semarang dan Makasar. Hardyanti dkk.(2017) menjelaskan bahwa suhu permukaan daratan yang tinggi di Jakarta terdapat pada wilayah terbangun dengan kerapatan pemukiman tinggi, vegetasi rendah dan merupakan wilayah industri, serta Central Business District (CBD). Hal serupa dilakukan oleh Sobirin \& Fatimah (2015) di Surabaya dan Maru dkk. (2015) di Makassar. Hasilnya menunjukkan bahwa arah perubahan atau peningkatan suhu perkotaan semakin meluas mengikuti perkembangan wilayah terbangun dengan suhu tertinggi berada di pusat kota. Darlina dkk. (2018) menyatakan bahwa suhu permukaan di Semarang setiap tahun semakin meningkat khususnya di pusat 
Kota dan Semarang Selatan. Kenaikan suhu tersebut dipengaruhi oleh tutupan lahan dan bertambahnya jumlah penduduk.

Berdasarkan beberapa penelitian terkait UHI, maka dapat diketahui beberapa faktor yang mempengaruhi terjadinya UHI di dalam kawasan perkotaan. Reuben (2012) mengidentifikasi ada empat faktor yang mempengaruhi terjadinya UHI, yaitu: struktur perkotaan, tutupan kota, urban fabric dan metabolisme perkotaan. Urban fabric adalah hal yang berkaitan dengan penyerapan panas, pemantulan (albedo) dan konduktivitas. Permukaan jalan yang tertutup oleh lapisan aspal dan beton akan lebih panas dibandingkan permukaan yang tertutup tanah atau vegetasi.

Rizwan dkk. (2008) menyatakan bahwa terdapat dua faktor yang mempengaruhi UHI suatu kota, yaitu faktor terkontrol dan tidak terkontrol. Faktor terkontrol terkait populasi dan area hijau serta bangunan perkotaan, sedangkan faktor tidak terkontrol terkait parameter cuaca seperti tutupan awan, kecepatan angin dan musim.

Melihat faktor-faktor yang mempengaruhi terjadinya UHI, terdapat beberapa kesamaan antara kota yang satu dengan kota lainnya. Salah satunya adalah faktor tutupan lahan, khususnya berkurangnya tutupan vegetasi yang ada di kota-kota besar setiap tahunnya. Seperti yang telah dikatakan oleh Yunus (2005) bahwa perkembangan kota-kota besar cenderung tidak dipantau dengan ketat, sehingga menyebabkan pertumbuhan kota yang tidak terarah. Berkurangnya tutupan vegetasi yang ada di kota besar berdampak pada berkurangnya jumlah ruang terbuka hijau yang seharusnya dimiliki oleh sebuah kota untuk mencapai keseimbangan ekologis. Joga \& Ismaun (2011) mengatakan bahwa konversi ruang terbuka hijau menjadi kawasan terbangun di kawasan perkotaan semakin tidak terkendali. Padahal ruang hijau perkotaan merupakan komponen penting dalam menjaga keseimbangan ekosistem kawasan perkotaan. Kebutuhan ruang terbuka hijau suatu kawasan perkotaan sendiri dapat dilihat secara kualitatif maupun kuantitatif. Perhitungan luas minimum ruang terbuka hijau secara kuantitatif dapat didasarkan pada luas wilayahnya, jumlah penduduk dan kebutuhan oksigen.

Menurut Undang-Undang Republik Indonesia Nomor 26 Tahun 2007 Tentang Penataan Ruang, proporsi ruang terbuka hijau pada wilayah kota paling sedikit $30 \%$ dari luas wilayah kota. Dengan proporsi ruang terbuka hijau publik paling sedikit 20 $\%$ dan ruang terbuka privat paling sedikit $10 \%$. Pada kenyataannya, masih banyak kota-kota besar yang tidak menerapkan ketentuan perundangan tersebut. Bahkan pemerintah kota sendiri merasa kesulitan dalam menyediakan lahan untuk ruang terbuka hijau. Kebutuhan akan ruang terbuka hijau kurang bernilai ekonomis, khususnya di dalam kawasan perkotaan. Kurangnya luasan ruang terbuka hijau di perkotaan menjadi alasan mengapa fenomena UHI banyak terjadi di kota-kota besar baik di luar negeri maupun di Indonesia.

Kota Makassar merupakan salah satu kota di Indonesia yang menghasilkan fenemona UHI di kawasan perkotaan. Maru $d k k$. (2015) meneliti tentang fenomena UHI yang terjadi di Makassar. Hasilnya menunjukkan bahwa terdapat perbedaan yang sangat jelas antara suhu permukaan di pusat kota yang relatif lebih tinggi dengan suhu di pinggiran serta suhu permukaan yang tertutup vegetasi. Besarnya konversi lahan kawasan non-terbangun menjadi kawasan terbangun menjadi alasan berkurangnya ruang terbuka hijau di Kota 
Makassar. Kota ini sendiri merupakan pintu masuk perdagangan dan perekonomian menuju kawasan Indonesia Timur sehingga pemerintah kota berupaya untuk meningkatkan infrastruktur untuk pemenuhan aktifitas perekonomiannya.

Berdasarkan pada Rencana Tata Ruang Kota Makassar tahun 2015-2034, jumlah ruang terbuka hijau di Makassar hanya sebesar $8,31 \%$ dari luas wilayahnya. Proporsi luasan ruang terbuka hijau ini jelas masih sangat kurang dari ketentuan perundangan yang mensyaratkan minimal $30 \%$.

Shishegar (2014) menjelaskan bahwa salah satu upaya yang efektif dan efisien untuk mengurangi UHI sekaligus untuk meningkatkan kualitas hidup dan kesehatan masyarakat perkotaan adalah dengan melakukan penambahan ruang terbuka hijau. Selain itu, faktor lain yang mempengaruhi UHI di kota besar, yaitu kerapatan bangunan dan pertambahan jumlah penduduk. Menurut Limas $d k k$. (2014) jumlah penduduk, indeks pembangunan manusia (IPM) dan pemakaian listrik mendukung naiknya indeks suhu permukaan Kota Jakarta.

Meskipun Fenomena UHI yang terjadi di kota-kota besar tidak terlalu berdampak pada pemanasan global, akan tetapi dampak yang dikibatkan oleh panas UHI jelas sangat dirasakan oleh masyarakat perkotaan itu sendiri khususnya di Kota Makassar. Dampak UHI meliputi penggunaan konsumsi energy berlebih, kesehatan dan ketidaknyamanan (Maru $d k k$. 2015).

Dengan melihat dampak yang ditimbulkan oleh fenomena UHI di Kota Makassar, maka diperlukan suatu upaya oleh pemerintah kota, swasta dan masyarakat untuk mengurangi dampak dari UHI itu sendiri. Kajian mengenai UHI perlu dilakukan mengingat setiap tahun suhu permukaan semakin meningkat. Tujuan dari penelitian ini difokuskan pada pemetaan sebaran ruang terbuka hijau dengan persentase luasannya serta distribusi sebaran UHI yang terjadi di Kota Makassar. Diharapkan dengan adanya penelitian ini dapat membantu masyarakat dalam meminimalisir peningkatan UHI dan dapat membantu pemerintah daerah yang bergerak di bidang perencanaan ruang dalam membuat kebijakan, khususnya terkait dengan kebijakan ruang terbuka hijau yang dapat meminimalisir dampak dari UHI tersebut.

\section{METODE PENELITIAN Rancangan Penelitian}

Penelitian ini dilakukan di Kota Makassar dengan fokus kawasan perkotaan yang terdiri atas 11 kecamatan dan 120 kelurahan (Gambar 1). Metode yang digunakan yaitu kuantitatif-deduktif dengan analisis penginderaan jauh untuk mengetahui perubahan luasan ruang terbuka hijau, perubahan suhu permukaan serta perubahan UHI yang terjadi tahun 2013 dan 2018.

Berdasarkan data pada kedua tahun tersebut, maka dapat diketahui besar perubahan ruang terbuka hijau dan rentang perubahan suhu dari tahun 2013 sampai 2018. Survey lapangan dilakukan dengan mengambil beberapa sampel untuk menguji hasil klasifikasi pada citra dan melihat kondisi ruang terbuka hijau yang ada di lapangan. Adapun kerangka alur penelitian terlihat pada Gambar 2. 


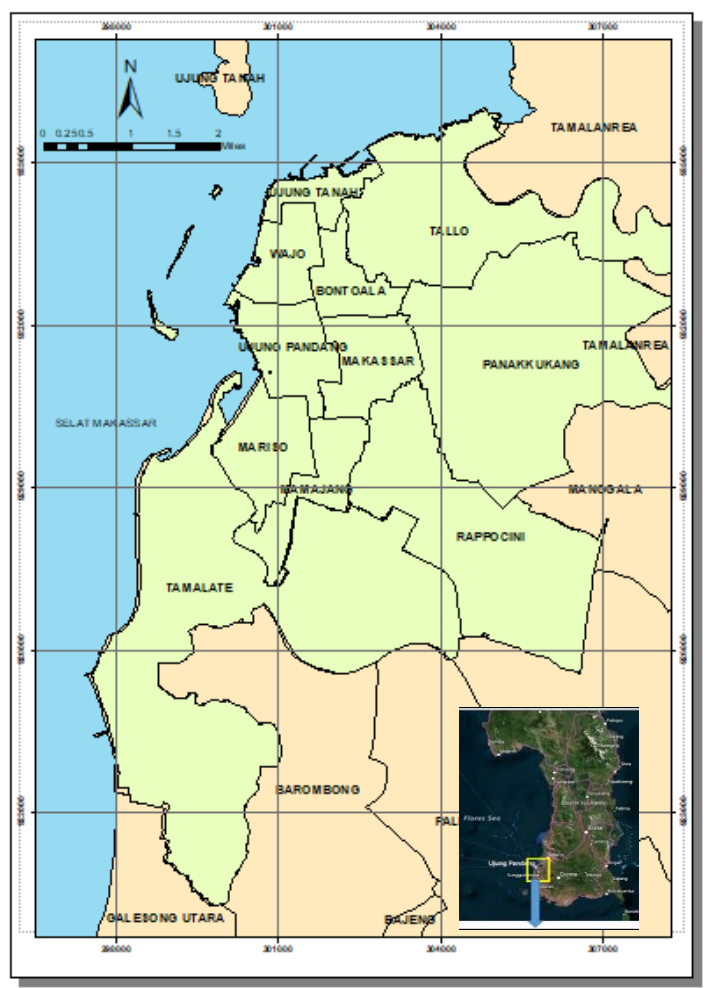

Gambar 1.

Peta Administrasi Kota Makassar (Sumber: BPN Kota Makassar, 2017)

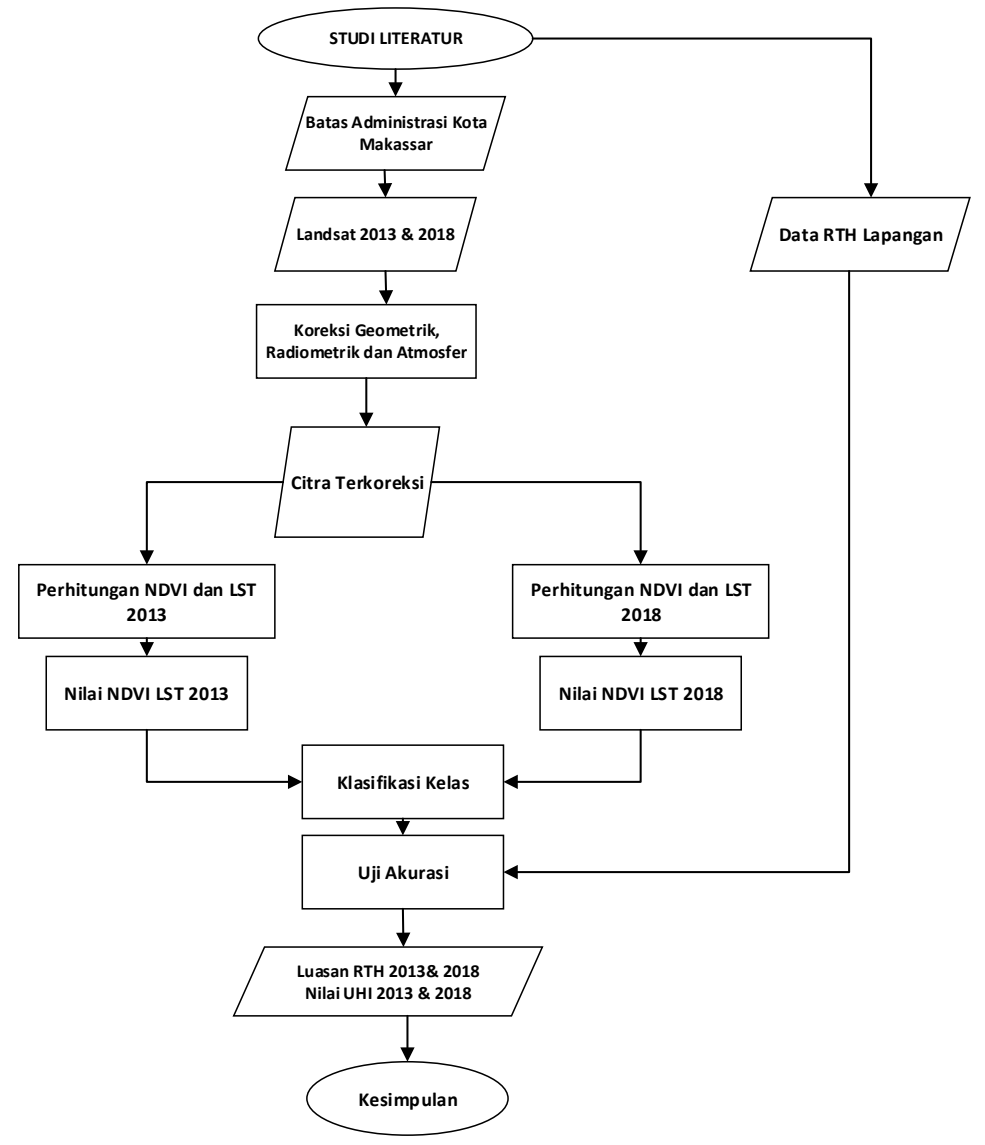

Gambar 2.

Kerangka Alur penelitian 


\section{Pengumpulan Data}

Penelitian ini menggunakan data primer berupa citra satelit Landsat 8 OLI/TIRS Tahun 2013 dan 2018 yang diunduh dari website US Geological Survey (USGS) (http://glovis.usgs.gov/) untuk mendapatkan nilai NDVI dan LST. Selain itu data lain diperoleh dari survey lapangan untuk pemeriksaan akurasi klasifikasi pada kelas vegetasi. Jumlah titik sampel disesuaikan dengan jumlah kelas vegetasi pada tahun 2018 yang dibagi menjadi empat kelas, dengan masing-masing kelas memiliki 10 sampel. Total sampel yang diperiksa berjumlah 40 sampel. Pengumpulan data sekunder diperoleh dari beberapa instansi terkait. Data sekunder yang digunakan adalah data administrasi dari BPN Kota Makasar, Data RTRW dari Dinas Tata Ruang Kota Makassar, data suhu harian dari BMKG Kota Makassar serta wawancara beberapa pegawai pemerintah kota. Wawancara tersebut dilakukan untuk memperoleh jajak pendapat dari sejumlah sampel di wilayah studi. Hasil wawancana ini kemudian dibandingkan dengan hasil penelitian untuk menentukan strategi pengurangan UHI yang tepat di daerah studi.

\section{Pengolahan Data}

Pengolahan diawali dengan melakukan pengolahan Citra Landsat tahun 2013 dan 2018 dengan melakukan koreksi radiometrik dan koreksi atmosfer. Hasil tersebut kemudian dipotong berdasarkan lokasi penelitian dengan menggunakan peta batas administrasi. Setelah itu kemudian dilakukan pengolahan data untuk mendapatkan nilai kehijauan vegetasi dan suhu permukaan. Berikut adalah tahapan pengolahan data yang dilakukan:

1. Pengolahan nilai vegetasi untuk mendapatkan kelas dan luasan vegetasi.
Nilai vegetasi wilayah penelitian ini dilakukan dengan menggunakan metode Normalized Difference Vegetation Index (NDVI). NDVI merupakan indeks kehijauan atau aktivitas fotosintesi vegetasi yang paling sering digunakan untuk memperoleh kerapatan vegetasi suatu wilayah (Sinaga $d k k ., 2018$ ). Nilai ini berkisar dari -1 sampai +1 . Semakin mendekati nilai 1 menunjukkan semakin rapatnya vegetasi di wilayah tersebut. Nilai NDVI pada citra Landsat 8 dapat dihitung dengan Rumus 1.

$$
N D V I=\frac{(N I R-R E D)}{(N I R+R E D)} \text {. }
$$

dengan:

NIR = Near Infrared Reflectance atau sinar inframerah dekat (Band 5 Landsat 8)

RED $=$ Red Reflectance atau pantulan sinar merah. (Band 4 Landsat 8)

2. Uji akurasi

Uji akurasi hasil interpretasi klasifikasi pada citra dengan keadaan yang ada di lapangan dapat dilakukan dengan menggunakan matriks konfusi (Confusion Matrix). Parameter yang digunakan dicari dengan Rumus 2 dan 3.

$$
\begin{aligned}
& \text { Overall Acc. }= \\
& \frac{\text { Total diagonal utama }}{\text { Jumlah pixel/ sampel }} \times 100 \% \\
& \kappa=\frac{\theta 1-\theta 2}{1-\theta 2}
\end{aligned}
$$

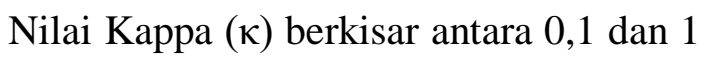
dengan nilai yang lebih besar menunjukkan semakin baik akurasinya.

3. Pengolahan suhu permukaan untuk mendapatkan nilai UHI. Beberapa tahapan dalam proses perhitungan UHI adalah sebagai berikut:

a) Perhitungan konversi nilai piksel ke nilai radian spectral menggunakan Rumus 4.

$$
L \lambda=M L * Q_{\text {cal }}+A L
$$


dengan:

$\mathrm{L} \lambda=$ radian spektral pada sensor $\left(\mathrm{W} /\left(\mathrm{m}^{2} \cdot \mathrm{sr} \cdot \mu \mathrm{m}\right)\right)$,

Qcal = nilai piksel $(\mathrm{DN})$,

ML = konstanta rescaling, diperoleh pada metadata citra

$\mathrm{AL}=$ konstanta penambah, diperoleh pada metadata citra.

b) Perolehan suhu radian tidak lepas dari nilai koreksi emisivitas tanah dan vegetasi. Penelitian ini mengacu pada Valor \& Caselles (1996), yaitu menggunakan nilai emisivitas vegetasi seperti Rumus 5.

$\varepsilon v=0,985 \pm 0,007$

c) Penentuan nilai koreksi Atmosfer (Top of Atmosphere, TOA) didasarkan pada nilai Radiative Transfer Equation untuk mengkoreksi faktor atmosfer yang mempengaruhi radiasi yang dipancarkan oleh objek.

d) Perhitungan nilai koreksi Suhu Permukaan (Land Surface Temperature, LST) dengan menggunakan nilai yang telah terkoreksi (emissivitas dan atmosfer). Hasilnya adalah estimasi suhu permukaan tahun 2013 dan tahun 2018. Persamaan yang digunakan untuk menghitung nilai di atas dapat dilihat pada Rumus 6 .

$$
T_{\text {rad }}=\frac{K_{2}}{\ln \left(\frac{K_{1}}{L_{\text {sensor }, \lambda}}+1\right)}
$$

dengan:

$\mathrm{T}_{\mathrm{rad}}=$ suhu radian dalam satuan Kelvin (K)

$\mathrm{L} \lambda$-e $=$ nilai radian spektral terkoreksi emisivitas

$\mathrm{K} 1=$ Konstanta kalibrasi radian spektral (W/(m2.sr. $\mu \mathrm{m}), \quad$ diperoleh pada metadata untuk band 10

K2 = Konstanta kalibrasi suhu absolut (K), diperoleh pada metadata untuk band 10 atau 11.

Hasil dari suhu permukaan yang terkoreksi kemudian dilakukan ekstraksi UHI dengan menggunakan Rumus 7 dan 8 (Fawzi, 2017):

$$
\begin{aligned}
& T>\mu+0,5 \alpha \ldots \ldots \\
& 0<T \leq \mu+0,5 \alpha
\end{aligned}
$$

dengan:

$\mathrm{T}=$ Suhu permukaan (LST)

$\mu=$ Nilai rata-rata suhu permukaan

$\alpha=$ Standar deviasi suhu permukaan

Rumus (7) menunjukan daerah yang tidak terdampak UHI, sedangkan Rumus (8) menunjukan daerah yang terdampak oleh UHI dengan suhu melebihi ambang batas tertentu.

\section{HASIL DAN PEMBAHASAN \\ Sebaran dan luasan vegetasi Kota \\ Makassar}

Nilai dari NDVI pada penelitian ini terdiri atas nilai NDVI tahun 2013 dengan rentang nilai -0.33 sampai dengan +0.583 , dan nilai NDVI pada tahun 2018 dengan rentang nilai -0.28 sampai dengan 0.63 . Kehijauan vegetasi kemudian diklasifikasikan menjadi 5 kelas seperti terlihat pada Tabel 1 . 
Tabel 1.

Klasifikasi rentang nilai vegetasi di Kota

Makassar

\begin{tabular}{|c|c|c|c|}
\hline$\overline{\text { Kelas }}$ & $\begin{array}{c}\text { Rentang } \\
\text { Kelas }\end{array}$ & $\begin{array}{c}\text { Kerapatan } \\
\text { Vegetasi }\end{array}$ & Jenis \\
\hline Kelas 1 & $<0$ & Non Vegetasi & $\begin{array}{c}\text { Badan air, } \\
\text { perairan }\end{array}$ \\
\hline Kelas 2 & $0-0,1$ & $\begin{array}{c}\text { Vegetasi } \\
\text { Sangat Rendah }\end{array}$ & $\begin{array}{c}\text { Tanah yang } \\
\text { tertutup aspal, } \\
\text { paving }\end{array}$ \\
\hline Kelas 3 & $0,1-0,3$ & $\begin{array}{l}\text { Vegetasi } \\
\text { Rendah }\end{array}$ & $\begin{array}{c}\text { Lapangan, } \\
\text { Rerumputan, } \\
\text { Semak } \\
\text { Belukar }\end{array}$ \\
\hline Kelas 4 & $0,3-0,6$ & $\begin{array}{l}\text { Vegetasi } \\
\text { Sedang }\end{array}$ & $\begin{array}{c}\text { Kebun } \\
\text { Campuran, } \\
\text { Alang-alang }\end{array}$ \\
\hline Kelas 5 & $>0,6$ & $\begin{array}{c}\text { Vegetasi } \\
\text { Tinggi }\end{array}$ & Pepohonan \\
\hline
\end{tabular}

Dengan melihat rentang nilai NDVI tahun 2013 serta merujuk pada tabel klasifikasi rentang nilai vegetasi maka terlihat bahwa pada tahun 2013 masih terdapat nilai vegetasi tinggi karena masih terdapat rentang nilai vegetasi $>0,6$ sedangkan pada tahun 2018 vegetasi tinggi tersebut hilang sehingga hanya terdapat kerapatan vegetasi sedang.

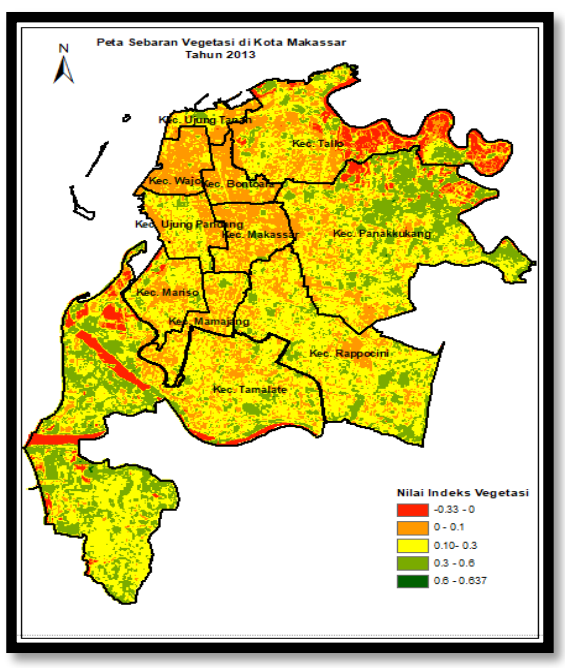

Gambar 3: Sebaran vegetasi di Kota Makassar tahun 2013

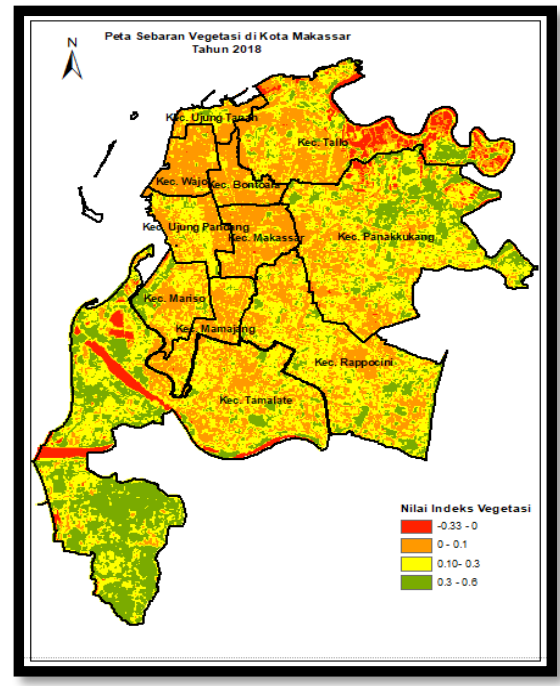

Gambar 4.

Sebaran vegetasi di Kota Makassar tahun 2013

Gambar 3 dan Gambar 4 di atas merupakan visualisasi sebaran vegetasi di Kota Makassar tahun 2013 dan tahun 2018.

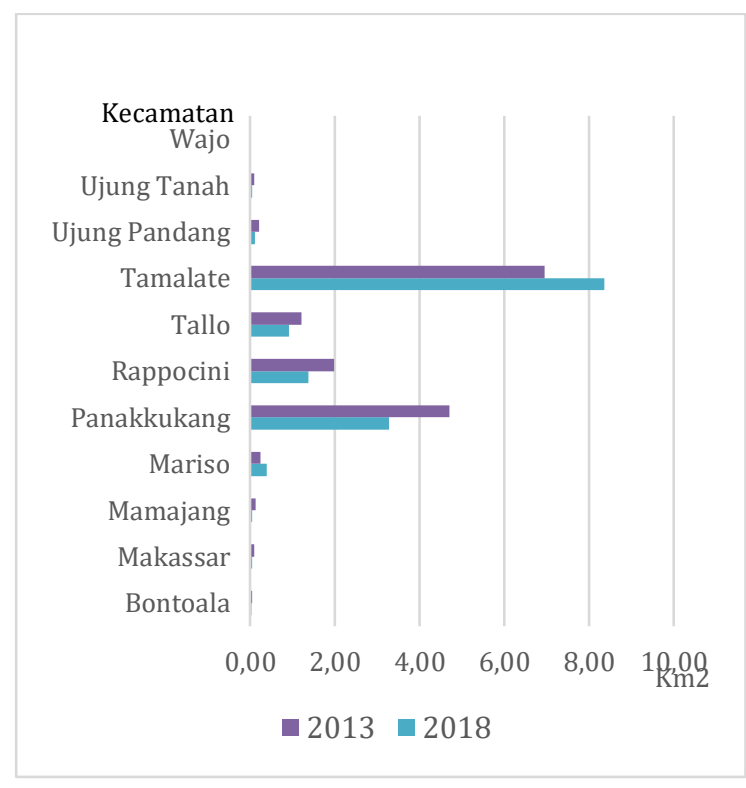

Gambar 5.

Diagram Perubahan luasan RTH tahun 2013 dan tahun 2018

Gambar 5 menunjukkan bahwa perubahan cukup terlihat pada Kecamatan Panakukkang dan Kecamatan Rappocini. Kecamatan Panakukkang mengalami penurunan luasan ruang terbuka hijau paling tinggi yaitu sebesar $1.42 \mathrm{~km}^{2}$ dan 
diikuti oleh Kecamatan Rappocini yaitu sebesar $0.62 \mathrm{~km}^{2}$.

Kedua kecamatan tersebut (Panakkukang dan Rappocini) merupakan pusat pelayanan, pusat bisnis (Central Bisnis District) dan perekonomian Kota Makassar. Secara keseluruhan perubahan luasan ruang terbuka hijau pada lokasi penelitian dapat dilihat pada Tabel 2 .

Tabel 2.

Luasan ruang terbuka hijau di Kota Makassar

\begin{tabular}{cccc}
\hline Tahun & $\begin{array}{c}\text { Luasan } \\
\left(\mathbf{k m}^{2}\right)\end{array}$ & $\begin{array}{c}\text { Luas RTH } \\
\text { Ideal (UUPR } \\
\mathbf{2 6 / 2 0 0 7 )}\end{array}$ & $\begin{array}{c}\text { Kekurangan } \\
\left(\mathbf{k m}^{2}\right)\end{array}$ \\
\cline { 1 - 2 } 2013 & 15.71 & & \\
\cline { 1 - 2 } 2018 & 14.67 & 22.93 & 8.26 \\
\cline { 1 - 2 } Selisih & 1.042 & & \\
\hline
\end{tabular}

Tabel 2 menunjukkan bahwa luasan ruang terbuka hijau tahun 2013 masih sangat jauh dari luasan ruang terbuka yang diamanatkan, bahkan luasan tersebut semakin berkurang pada tahun 2018. Secara keseluruhan, dengan mengambil klasifikasi sedang dan tinggi (Tabel 1) serta berdasarkan Tabel 2 untuk menjelaskan luasan ruang terbuka hijau di Kota Makassar, maka luasan ruang terbuka hijau pada tahun 2013 sebesar $15.71 \mathrm{~km}^{2}$ dan luasan ruang terbuka hijau pada tahun 2018 sebesar $14.67 \mathrm{~km}^{2}$, sehingga terdapat pengurangan luasan sebesar $1.04 \mathrm{~km}^{2}$ dari tahun 2013 ke tahun 2018.

Perubahan tersebut terjadi khususnya pada kecamatan-kecamatan yang berada di pusat Kota Makassar akibat tingginya pembangunan ruko, pusat perbelanjaan dan juga perumahan. Pemerintah kota sebenarnya sudah mengantisipasi berkurangnya ruang terbuka hijau dengan memberikan Peraturan Walikota Nomor 69 Tahun 2016 dan Peraturan Daerah Nomor 3
Tahun 2014 tentang penataan dan pengelolaan ruang terbuka hijau di Kota Makassar. Akan tetapi, karena kurangnya pengawasan yang ketat serta tidak adanya sanksi yang tegas saat proses pembangunan berjalan tidak sesuai dengan aturan, maka luasan ruang terbuka hijau di kawasan perkotaan semakin berkurang setiap tahunnya.

\section{Uji akurasi klasifikasi vegetasi}

Proses uji akurasi dilakukan dengan menentukan jumlah sampel yang akan diamati di lapangan. Dalam hal ini jumlah sampel yang diambil yaitu berjumlah 40 sampel pada masing-masing kelas klasifikasi. Dari hasil uji akurasi dengan matriks konfusi diperoleh nilai akurasi keseluruhan sebesar 82,5\% dan nilai Kappa sebesar 0,25. Dengan demikian dapat dikatakan bahwa klasifikasi NDVI pada citra dengan kondisi di lapangan memiliki ketepatan yang lumayan (fair), sehingga hasilnya dapat dilanjutkan untuk pengolahan selanjutnya.

\section{Analisis Urban Heat Island di Kota Makassar}

Nilai Urban Heat Island di Kota Makassar menggunakan analisis nilai suhu permukaan yang diperoleh dari Citra Landsat 8 tahun 2013 dan nilai suhu permukaan pada Citra Landsat 8 tahun 2018. Nilai suhu permukaan (LST) merupakan komponen yang digunakan untuk menghitung ambang batas UHI yang terjadi pada tahun penelitian.

Dari gambar 6 terlihat bahwa suhu permukaan Kota Makassar mengalami kenaikan di seluruh kecamatan. Terdapat tiga kecamatan yang mengalami peningkatan suhu cukup tinggi dari tahun 2013 ke tahun 2018, yaitu Kecamatan Tallo, Kecamatan Makassar dan Kecamatan Panakukkang. Merujuk pada RTRW Kota 
Makassar, Kecamatan Tallo merupakan kawasan yang difokuskan untuk kegiatan maritim atau pusat kegiatan aktivitas perdagangan kapal. Adapun Kecamatan Makassar merupakan pusat pemerintahan, sedangkan Kecamatan Panakukkang merupakan kawasan perdagangan.

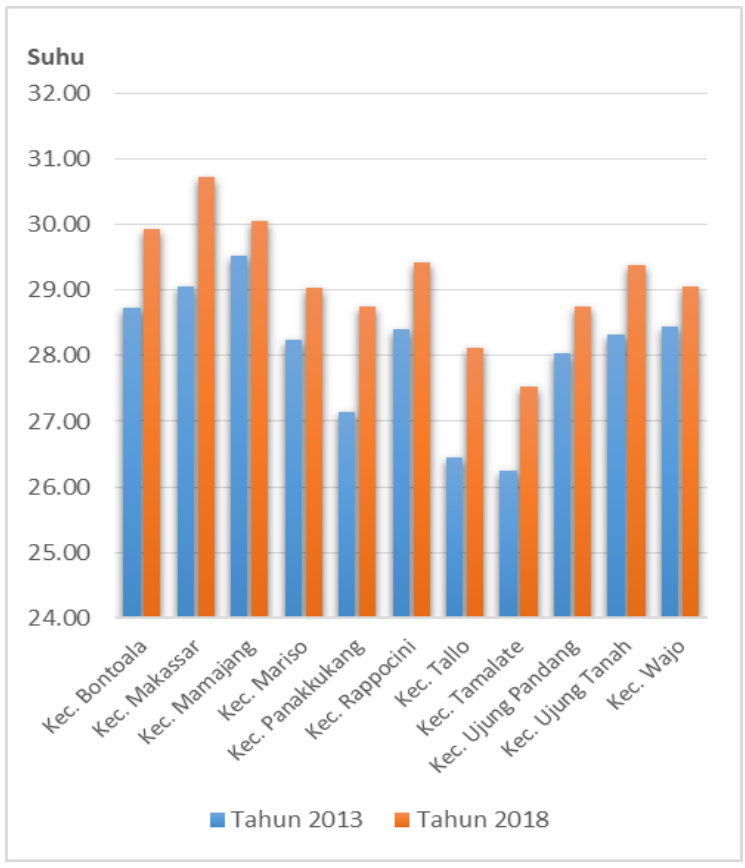

Gambar 6.

Diagram Perubahan suhu rata-rata permukaan tahun 2013 dan tahun 2018

Hasil dari suhu permukaan ini kemudian dilakukan pengolahan lebih lanjut untuk memperoleh nilai UHI. Dari hasil pengolahan diperoleh nilai ambang batas UHI pada tahun 2013 sebesar $28,42^{\circ} \mathrm{C}$, sedangkan nilai ambang batas UHI pada tahun 2018 sebesar $29,54^{\circ}$ C. Penelitian yang dilakukan oleh Marsitha $d k k$. (2019) tentang suhu kenyamanan termal yang terjadi di Kota Makassar menjelaskan bahwa suhu kenyamanan termal Kota Makassar hanya berkisar antara $25-27^{\circ} \mathrm{C}$, sehingga apabila suhu permukaan $>27^{\circ} \mathrm{C}$, maka sudah dikatakan tidak nyaman. Melihat nilai ambang batas UHI tahun 2013 yang sudah mencapai $>27^{\circ} \mathrm{C}$, maka dapat dikatakan bahwa sejak tahun 2013 sampai dengan 2018 fenomena UHI sudah terjadi di Kota Makassar. Nilai rentang UHI antara tahun 2013 berbeda dengan tahun 2018, dimana pada tahun 2013 nilai rentang UHI berkisar dari dari nilai -6,31 sampai dengan $+3,98$, sedangkan pada tahun 2018 rentang nilai UHI berkisar dari nilai $-5,85$ sampai $+4,35$. Dari nilai rentang tersebut terlihat juga bahwa terdapat kenaikan nilai UHI sebesar $1^{\circ} \mathrm{C}$ selama kurang lebih 5 tahun terakhir. Untuk melihat perbedaan wilayah yang terdampak UHI dari tahun 2013 sampai 2018, maka nilai UHI kemudian diklasifikasikan menjadi lima kelas yaitu Non UHI $(<0)^{\circ} \mathrm{C}$, UHI $1(0,01-1)^{\circ} \mathrm{C}$, UHI $2(1,01-2)^{\circ} \mathrm{C}$, UHI $3(2,01-3)^{\circ} \mathrm{C}$ dan UHI $4(>3)^{\circ} \mathrm{C}$. Adapun visualisasi sebaran nilai UHI pada tahun 2013 dan tahun 2018 dapat dilihat pada Gambar 7 dan Gambar 8 berikut:

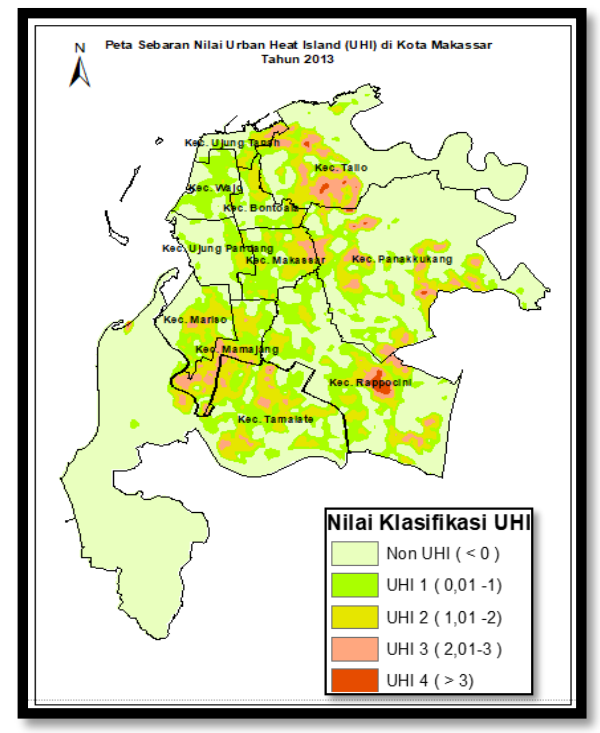

Gambar 7.

Sebaran Nilai UHI tahun 2013 




Gambar 8.

Sebaran Nilai UHI tahun 2013

Dari Gambar (7) dan Gambar (8), diperoleh kesimpulan bahwa pada tahun 2013 terdapat lima kelas UHI, dimana kelas UHI tertinggi yaitu UHI 4 terletak pada bagian utara dan timur selatan Kota Makassar. Akan tetapi, pada tahun 2018 terdapat perubahan pola spasial pada kelas UHI 4, yaitu kelas UHI 4 berada terpusat di tengah atau pusat kota.

Merujuk pada Tabel 3, maka dapat dikatakan untuk nilai UHI 1 sampai dengan UHI 3 hampir terjadi pada semua kecamatan yang ada di Kota Makassar. Perbedaannya terlihat pada nilai UHI 4. Luasan nilai UHI 4 bertambah dengan adanya penambahan satu kecamatan terdampak dari tahun 2013 ke tahun 2018 yaitu pada Kecamatan Makassar.

Dengan membandingkan antara kecamatan yang terdampak UHI tahun 2018 dan kecamatan yang mengalami pengurangan ruang terbuka hijau tertinggi, maka terdapat kesamaan bahwa Kecamatan Rappocini dan Kecamatan Panakukang merupakan kecamatan yang mengalami kondisi suhu tertinggi dengan penurunan luasan ruang terbuka hijau yang terbesar. Dengan membandingkan antara luasan ruang terbuka hijau ideal sesuai dengan UUPR No 26 tahun 2007 diperoleh luasan RTH ideal sebesar $22.93 \mathrm{~km}^{2}$ dari keseluruhan luas wilayah penelitian, sehingga terdapat kekurangan sebesar 8.25 $\mathrm{km}^{2}$.

Dari hasil tersebut, diperoleh bahwa nilai UHI tertinggi terdapat di pusat kota dengan kerapatan bangunan yang tinggi, dimana kawasan tersebut merupakan pusat pemerintahan, Central Business District (CBD) dan pusat pelayanan. Kecamatan Panakukkang dan Kecamatan Rappocini memiliki pengurangan luasan ruang terbuka hijau yang lebih banyak dibandingkan kecamatan lainnya serta memiliki nilai UHI yang paling tinggi.

Tabel 3.

Persentase luasan terdampak terhadap kelas UHI

\begin{tabular}{cccccccc}
\hline \multirow{2}{*}{$\begin{array}{c}\text { Kelas } \\
\text { UHI }\end{array}$} & Rentang & \multicolumn{2}{c}{$\begin{array}{c}\text { Luas area } \\
(\mathbf{K m} \mathbf{2})\end{array}$} & \multicolumn{2}{c}{$\begin{array}{c}\text { Persentase } \\
\text { luas }(\boldsymbol{\%})\end{array}$} & \multicolumn{2}{c}{ Kecamatan terdampak } \\
& & $\mathbf{2 0 1 3}$ & $\mathbf{2 0 1 8}$ & $\mathbf{2 0 1 3}$ & $\mathbf{2 0 1 8}$ & $\mathbf{2 0 1 3}$ & $\mathbf{2 0 1 8}$ \\
\hline Non & $<0$ & 45.98 & 48.38 & 60.52 & 63.76 & Semua Kecamatan & Semua Kecamatan \\
UHI & & & & & & & \\
\hline UHI 1 & $0,01-1$ & 15.77 & 15.87 & 20.78 & 20.92 & Semua Kecamatan & Semua Kecamatan \\
\hline UHI 2 & $1,01-2$ & 10.61 & 8.74 & 13.98 & 11.52 & Semua Kecamatan & Semua Kecamatan \\
\hline
\end{tabular}




\begin{tabular}{|c|c|c|c|c|c|c|c|}
\hline \multirow{2}{*}{$\begin{array}{c}\text { Kelas } \\
\text { UHI }\end{array}$} & \multirow{2}{*}{$\begin{array}{c}\text { Rentang } \\
\text { Nilai }\end{array}$} & \multicolumn{2}{|c|}{$\begin{array}{l}\text { Luas area } \\
(\mathrm{Km} 2)\end{array}$} & \multicolumn{2}{|c|}{$\begin{array}{c}\text { Persentase } \\
\text { luas }(\%)\end{array}$} & \multicolumn{2}{|c|}{ Kecamatan terdampak } \\
\hline & & 2013 & 2018 & 2013 & 2018 & 2013 & 2018 \\
\hline UHI 3 & $2,01-3$ & 3.31 & 2.54 & 4.36 & 3.35 & $\begin{array}{c}\text { Sebagian Kec. Tallo } \\
\text { Kec. Panakukkang } \\
\text { Kec. Mamajang } \\
\text { Kec. Rappocini, } \\
\text { Kec. Tamalate } \\
\text { Kec. Ujung Tanah } \\
\text { Sebagian Kec.Mariso }\end{array}$ & $\begin{array}{c}\text { Kec. Tallo } \\
\text { Kec. Panakukkang, } \\
\text { Kec. Mamajang } \\
\text { Kec.Rappocini } \\
\text { Sebagian Kec. } \\
\text { Tamalate } \\
\text { Kec. Makassar } \\
\text { Sebagian Kec. } \\
\text { Bontoala }\end{array}$ \\
\hline UHI 4 & $>3$ & 0.26 & 0.33 & 0.35 & 0.44 & $\begin{array}{c}\text { Kec. Tallo, } \\
\text { Sebagian Kec. } \\
\text { Panakukkang } \\
\text { Kec. Rappocini }\end{array}$ & $\begin{array}{c}\text { Kec. Tallo } \\
\text { Kec.Panakukkang } \\
\text { Kec. Rappocini } \\
\text { Kecamatan } \\
\text { Makassar }\end{array}$ \\
\hline
\end{tabular}

Berdasarkan wawancara yang telah dilakukan oleh penulis terhadap beberapa pegawai pemerintah di Kota Makassar pada tahun 2018, dapat disimpulkan bahwa pemerintah kota sebenarnya telah mengusahakan berbagai upaya untuk menambah jumlah ruang terbuka hijau yang ada di pusat Kota Makassar. Akan tetapi karena adanya kendala kurangnya lahan kosong yang tersedia maka realisasi penambahan luas ruang terbuka hijau setiap tahunnya masih sangat minim. Masyarakat juga masih enggan untuk memberikan sebagian tanah mereka untuk ruang terbuka hijau atau ingin memberikan dengan harga tanah yang tinggi sehingga pemerintah kota harus menyediakan anggaran yang cukup besar dalam pemenuhan luasan ruang terbuka hijau. Oleh karena itu penelitian ini diharapkan dapat memberikan gambaran kepada pemerintah kota khususnya perencana kota untuk tepat sasaran dalam memilih lokasi RTH sesuai dengan kondisi UHI setiap tahunnya, khususnya di Kota Makassar.

Ada beberapa upaya yang dapat dilakukan untuk mengurangi UHI dengan adanya kendala kurangnya lahan. Menurut
Giguère (2012), upaya pengurangan UHI dapat dilakukan dengan cara Urban Greening Stategy yang meliputi seleksi kualitas pohon dan vegetasi, menghijaukan lahan parkir, Green Walls serta Green Roofs. Dengan demikian dapat dikatakan bahwa selain menambah kuantitas ruang terbuka hijau pada kawasan yang terdampak, kualitas atau jenis vegetasi pada kawasan tersebut juga harus diperhatikan. Perlunya sosialisasi terkait pentingnya ruang terbuka hijau dan fenomena UHI yang meningkat setiap tahun harus menjadi kegiatan rutin yang dilakukan oleh Pemerintah Kota Makassar kepada masyarakat awam dan juga pihak swasta sehingga diharapkan dapat mengurangi dampak UHI pada lingkungan sekitar.

\section{SIMPULAN}

Penelitian ini menunjukkan hubungan antara fenomena Urban Heat Island (UHI) di Kota Makassar dengan luasan Ruang Terbuka Hijau (RTH) menggunakan analisis NDVI pada Landsat 8. Citra Landsat 8 pada tahun 2013 dan 2018 digunakan untuk mengetahui perubahan kondisi UHI dan perubahan luasan ruang terbuka hijau. Berdasarkan pada hasil 
perubahan kondisi UHI pada tahun 2013 dan 2018, dapat diketahui bahwa fenomena urban heat sudah terjadi di Kota Makassar pada tahun 2013, dimana suhu rerata sudah melebihi suhu nyaman di Kota Makassar. Rerata suhu ini juga dan mengalami kenaikan pada tahun 2018, khususnya pada daerah Central Bussiness District (CBD) di beberapa kecamatan di Kota Makassar.

Penelitian ini menunjukkan adanya pengurangan luasan RTH yang diikuti dengan kenaikan suhu pada tahun 2013 dan 2018. Diperoleh bahwa ketersediaan ruang terbuka hijau di Kota Makassar pada tahun 2018 kurang dari luasan RTH yang seharusnya tersedia sesuai dengan Undang- undang. Meskipun demikian, berdasarkan hasil wawancara diperoleh bahwa kurangnya ketersediaan lahan menyebabkan upaya penambahan RTH sangat sulit dilakukan. Dengan demikian, diperlukan langkah-langkah mitigasi UHI di Kota Makassar sebagai salah satu upaya untuk mengurangi fenomena UHI di masa yang akan datang. Upaya mitigasi tersebut dapat berupa Urban Green Strategy, Urban Roof dan Urban Wall yang dapat diterapkan khususnya di kecamatan dengan nilai rerata suhu permukaan tinggi di Kota Makassar, yaitu Kecamatan Rappocini, Kecamatan Panakkukang dan Kecamatan Makassar.

\section{DAFTAR PUSTAKA}

Darlina, S.P., Sasmito, B. \& Yuwono, B.D. 2018. Analisis Fenomena Urban Heat Island Serta Mitigasinya (Studi Kasus: Kota Semarang). Jurnal Geodesi Undip, 7(3): 77-87.

Fawzi, N.I. 2017. Mengukur Urban Heat Island Menggunakan Penginderaan Jauh, Kasus di Kota Yogyakarta. Majalah Ilmiah Globe, 19(2): 195-206.

Gaffin, S.R., Rosenzweig, C., Khanbilvardi, R., Parshall, L., Mahani, S., Glickman, H., Goldberg, R., Blake, R., Slosberg, R.B. \& Hillel, D. 2008. Variations In New York City's Urban Heat Island Strength Over Time And Space. Theoretical And Applied Climatology, 94(1-2): 111.

Gartland, L.M. 2012. Heat Islands: Understanding And Mitigating Heat In Urban Areas. Routledge.

Giguère, M. 2012. Literature Review Of Urban Heat Island Mitigation Strategies. Direction De La Santé Environnementale Et De La Toxicologie, Institut.

Hardyanti, L., Sobirin, S. \& Wibowo, A. 2017. Variasi Spasial Temporal Suhu Permukaan Daratan Di Kota Jakarta Tahun 2015 Dan 2016. Prosiding Industrial Research Workshop And National Seminar. Hlm.704-713.

Joga, N. \& Ismaun, I. 2011. Rth 30\%! Resolusi [Kota] Hijau. Gramedia Pustaka Utama.

Limas, A.V., Perdana, A., Nandhika, W. \& Tannady, H. 2014. Pembahasan Mengenai Efek Urban Heat Island Dan Solusi Alternatif Bagi Kota Jakarta. J@ Ti Undip: Jurnal Teknik Industri, 9(1): 29-34.

Marsitha, Femmy, Pattipeilohy, Wendel Jan \& Virgianto, Rista Hernandi 2019. Kenyamanan Termal Klimatologis Kota-Kota Besar Di Pulau Sulawesi Berdasarkan Temperature Humidity Index (Thi). Jurnal Saintika Unpam, 1: 202-211. 
Maru, R., Baharuddin, I.I., Umar, R., Rasyid, R., Uca, U., Sanusi, W. \& Bayudin, B. 2015. Analysis Of The Heat Island Phenomenon In Makassar, South Sulawesi, Indonesia. American Journal Of Applied Sciences, 12(9).

Reuben, L.M. 2012. Spatio-Temporal Dynamics Of The Urban Heat Island In Singapore. Phd Thesis. National University of Singapore, Singapore

Rizwan, A.M., Dennis, L.Y. \& Chunho, L.I.U. 2008. A Review On The Generation, Determination And Mitigation Of Urban Heat Island. Journal Of Environmental Sciences, 20(1): 120128.

Shishegar, N., 2014. The impact of green areas on mitigating urban heat island effect: A review. International Journal of Environmental Sustainability, 9(1), pp.119-130.

Sinaga, S.H., Suprayogi, A. \& Haniah, H. 2018. Analisis Ketersediaan Ruang Terbuka Hijau Dengan Metode Normalized Difference Vegetation Index Dan Soil Adjusted Vegetation Index Menggunakan Citra Satelit Sentinel-2a (Studi Kasus: Kabupaten Demak). Jurnal Geodesi Undip, 7(1): 202-211.

Sobirin, S. \& Fatimah, R.N. 2015. Urban Heat Island Kota Surabaya. Geo Edukasi, 4(2).

Valor, E. \& Caselles, V. 1996. Mapping Land Surface Emissivity From Ndvi: Application To European, African And South American Areas. Remote Sensing Of Environment, 57(3): 167-184.

Yunus, Hadi Sabari. 2005. Manajemen Kota. 1 Ed. 1. Yogyakarta: Pustaka Pelajar. 